\title{
Comparison of carcass and meat characteristics between male and female indigenous rabbit of Bangladesh
}

\author{
HM Murshed ${ }^{1}$, SR Shishir ${ }^{2}$, SME Rahman* ${ }^{1}$, Deog-Hwan $\mathrm{Oh}^{3}$ \\ ${ }^{1}$ Department of Animal Science; ${ }^{2}$ Department of Animal Nutrition, Bangladesh Agricultural University, Mymensingh \\ 2202, Bangladesh; ${ }^{3}$ Department of Food Science and Biotechnology, Kangwon National University, Chuncheon, \\ Korea
}

\begin{abstract}
This experiment was conducted to determine and compare some characteristics of the meat and carcass of rabbit aged 6 months according to sex. In the experiment six male and six female nondescript rabbits were slaughtered. The weight and percentage of warm carcasses, skin with head and limbs, liver, kidney, heart, lung, forelegs, hind legs, breast and ribs, loin and abdominal wall were recorded. The values for carcass length, lumbar circumference, drip loss, cooking loss, sensory characteristics were also determined. The mean values for warm carcass weight and warm dressing percentage were $698.33 \mathrm{~g}$ and $47.92 \%$ in male and $704.66 \mathrm{~g}$ and $48.55 \%$ in female, respectively. In case meat quality cooking loss, drip loss, proximate and sensory analyses was conducted. In this study significance difference was found in head, skin and limb weight $(93.34 \mathrm{~g})$ as well as in percentage $(6.46 \%)$ otherwise no significant differences were found between male and female rabbits in the characteristics of carcass and meat quality. Slaughter weight was significantly correlated with the weights of carcass, skin with head and limbs, lung, liver, kidney, heart and weight of joints and dressing percentage.
\end{abstract}

Key words: Carcass and meat characteristics, rabbit

Bangladesh Animal Husbandry Association. All rights reserved.

Bang. J. Anim. Sci. 2014. 43 (2): 154-158

\section{I ntroduction}

The importance of the domestic rabbit as a supplier of meat for human consumption is widely recognized throughout the world. In Europe and the United States commercial rabbit farming has been practiced for many years and standards of husbandry rose. There are also successful rabbit farms in the tropics and sub-tropics. The size of these varies from the large commercial rabbitries to small backyard rabbitries. Apart from being a good source of meat, rabbits provide useful skins, manure and, with some breeds wool. Rabbit meat is often relatively expensive in tropical countries, but this is more a function of its scarcity and small number of producers, and is not related to any problems in raising rabbits.

World production of rabbit meat was estimated at 1693 thousand tons in 2010. The largest producer was China $(669,000$ tons) followed by Italy $(255,000$ tons), South Korea $(133,000$ tons) and
Egypt (70,000 tons), (FAOSTAT 2010). I nformation on carcass characteristics is therefore helpful for the effective utilization of rabbit meat. Carcass and meat quality changes markedly with the animal's age or slaughter weight (Dalle 2002). These quality characteristics may also be affected by sex to different extent (Cavani et al. 2000).

In the study of Akıncı et al. (1998), carcass quality characteristics of New Zealand White and California rabbits were found to be significantly affected by age $(p<0.01)$ but not affected by sex. Relatively few studies have been made comparing the quality of the carcass and meat quality in sexes of rabbit. The purpose of this research is to determine and compare the quality of the meat and carcass in sexes of indigenous Rabbits aged six months.

\section{Materials and Methods}

This experiment was conducted in the Animal Science Field Laboratory and analytical Laboratory, 


\section{Carcass and meat characteristics of rabbit}

Department of Animal Science, Faculty of Animal Husbandry, Bangladesh Agricultural University.

Six male and six female indigenous rabbits fed a pellet diet $(17.70 \% \mathrm{CP}, 12.13 \mathrm{MJ} / \mathrm{kg} \mathrm{DE})$ were weighed and slaughtered at 6 months of age. Slaughtering is conducted by cutting the jugular veins and carotid arteries (Deltoro and Lopez 1985). After the limbs and head were removed, each carcass was skinned, the abdomen was opened, and gut and internal organs were removed. The weights of skin with head and limbs, liver, kidney, heart and lung were recorded. These weights were expressed as percentage of slaughter weight. The length of the carcass was obtained as the sum of two measurements: from the atlas vertebra to the 7th lumbar vertebra and from the 7 th lumbar vertebra to the ischium insertion point. The lumbar circumference was measured at the level of the 7th lumbar vertebra, including abdominal wall (Fernandez and Fraga 1996). Thereafter, the carcass was divided to determine the weights of joints. The fore legs, hind legs, breast and ribs, loin and abdominal wall were weighed. Their weights were expressed as percentage of warm carcass weight.

Cooking loss $(\mathrm{CL})$ was determined by cooking the meat (10-15 g) in an electric oven at $90^{\circ} \mathrm{C}$ for 30 min and weighing it $30 \mathrm{~min}$ later. $\mathrm{CL}$ is the ratio $(\times 100)$ of the difference in weight between the cooked and raw muscle relative to the weight of the raw muscle (Pla et al. 1998). The drip loss of the Longissimus dorsi muscle was measured by keeping the meat at $4^{\circ} \mathrm{C}$ for 24 hours. Drip Loss is the ratio $(\times 100)$ of the difference in weight between the meat kept at $4{ }^{\circ} \mathrm{C}$ for 24 hours and raw muscle relative to the weight of the raw muscle.

Proximate analysis was done to find out dry matter, moisture, ash and crude protein according to AOAC (2005). To evaluate sensory color and odor characteristics of raw meat and tenderness, juiciness and overall acceptance of cooked meat a 5-member trained sensory panel was used. A scale of 0 to 5 was used to differentiate meat characteristics.
Data were analyzed using SPSS for windows. Parameters were given as mean and standard error. Differences in parameters between male and female rabbits were studied using Student t tests. Correlation coefficients between parameters were calculated.

\section{Results and Discussion}

The mean values of the carcass and meat characteristics of indigenous rabbits and the correlation coefficients between some of these characteristics are presented in Table 1 and Table 2 , respectively.

Table 1. The values for the mean and standard error of the carcass and meat characteristics of rabbits

\begin{tabular}{lcc}
\hline \multicolumn{1}{c}{ Organ } & Male & Female \\
\hline Slaughter wt (g) & $1450(36.54)$ & $1451.33(16.58))$ \\
Warm carcass wt (g) & $698.33(25.72)$ & $704.66(15.52)$ \\
Warm carcass (\%) & $46.92(.65)$ & $48.55(.67)$ \\
Head, Skin and limbs (g) & $378.67(3.56)$ & $285.33(13.08)$ \\
Head, Skin and limbs (\%) & $26.12(.35)$ & $19.66(.29)$ \\
Lung wt (g) & $8.66(1.35)$ & $8(.58)$ \\
Lung (\%) & $0.58(.60)$ & $0.55(.02)$ \\
Liver wt (g) & $28.66(3.62)$ & $28(.61)$ \\
Liver (\%) & $1.98(.17)$ & $1.93(.04)$ \\
Kidney Wt (g) & $10(1.46)$ & $9.33(.89)$ \\
Kidney (\%) & $0.69(.07)$ & $0.64(.09)$ \\
Heart wt (g) & $4(1.03)$ & $4.67(.99)$ \\
Heart (\%) & $0.28(.01)$ & $0.32(.13)$ \\
Foreleg, Shoulder and Leg wt (g) & $92(1.98)$ & $90(1.53)$ \\
Foreleg, Shoulder and Leg (\%) & $6.34(.23)$ & $6.20(.17)$ \\
Hind leg and Rump wt (g) & $244(18.58)$ & $266(5.80)$ \\
Hind leg and Rump (\%) & $16.83(.73)$ & $18.34(.69)$ \\
Breast, neck and Ribs wt (g) & $141.33(9.32)$ & $146(2.46)$ \\
Breast, neck and Ribs (\%) & $9.75(.42)$ & $10.06(.43)$ \\
Loin and abdominal Wall wt (g) & $198.67(9.20)$ & $176(10.40)$ \\
Loin and abdominal Wall (\%) & $13.70(.14)$ & $12.14(.75)$ \\
Warm carcass Length (cm) & $34.67(.84)$ & $35(.81)$ \\
Lumber circumference Length (cm) & $15.16(.29)$ & $15.67(.33)$ \\
Hind leg length(cm) & $10.16(.31)$ & $10.67(.21)$ \\
Fore leg length (cm) & $5.16(.11)$ & $5(.13)$ \\
Hind limb length (cm) & $17.5(.17)$ & $16.33(.33)$ \\
Fore limb length (cm) & $13.67(.28)$ & $14.16(.28)$ \\
\hline & & \\
\hline
\end{tabular}

values in the parenthesis are the standard errors of the mean; Means with different superscript in the same row differed significantly $(p<0.01)$ 
Murshed et al. (2014) Bang. J. Anim. Sci. 43 (2): 154- 158

Table 2. Correlation coefficients among some carcass and meat characteristic

\begin{tabular}{lcccccccccccc}
\hline & SW & WCW & HSLN & LUNG & LIVER & KIDNEY & HEART & FLSL & HLR & BNR & LAW \\
\hline SW & 1 & $0.896^{\star \star}$ & -0.024 & 0.228 & $0.773^{\star \star}$ & 0.518 & 0.348 & 0.514 & 0.464 & $0.667^{\star}$ & 0.281 \\
WCW & $0.896^{\star \star}$ & 1 & -0.289 & 0.162 & $0.647^{\star}$ & 0.486 & 0.505 & 0.428 & $0.619^{\star}$ & $0.759^{\star \star}$ & 0.035 \\
HSLN & -0.024 & -0.289 & 1 & 0.052 & -0.019 & 0.181 & -0.307 & 0.362 & -0.329 & -0.197 & $0.614^{\star}$ \\
LUNG & 0.228 & 0.162 & 0.052 & 1 & $0.757^{\star \star}$ & $0.577^{\star}$ & 0.505 & 0.026 & -0.273 & $0.670^{\star}$ & 0.469 \\
LIVER & $0.773^{\star \star}$ & $0.647^{\star}$ & -0.019 & $0.757^{\star *}$ & 1 & $0.596^{\star}$ & 0.477 & 0.235 & 0.015 & $0.787^{\star \star}$ & 0.439 \\
KIDNEY & 0.518 & 0.486 & 0.181 & $0.577^{\star}$ & $0.596^{\star}$ & 1 & $0.608^{\star}$ & $0.653^{\star}$ & 0.477 & $0.665^{\star}$ & $0.623^{\star}$ \\
HEART & 0.348 & 0.505 & -0.307 & 0.505 & 0.477 & $0.608^{\star}$ & 1 & -0.036 & 0.465 & $0.703^{\star}$ & 0.281 \\
FLSL & 0.514 & 0.428 & 0.362 & 0.026 & 0.235 & $0.653^{\star}$ & -0.036 & 1 & 0.522 & 0.295 & 0.246 \\
HLR & 0.464 & $0.619^{\star}$ & -0.329 & -0.273 & 0.015 & 0.477 & 0.465 & 0.522 & 1 & 0.318 & -0.065 \\
BNR & $0.667^{\star}$ & $0.759^{\star \star}$ & -0.197 & $0.670^{\star}$ & $0.787^{\star \star}$ & $0.665^{\star}$ & $0.703^{\star}$ & 0.295 & 0.318 & 1 & 0.309 \\
LAW & 0.281 & 0.035 & $0.614^{\star}$ & 0.469 & 0.439 & $0.623^{\star}$ & 0.281 & 0.246 & -0.065 & 0.309 & 1 \\
\hline
\end{tabular}

** and * indicate the correlations are significant at the 0.01 and 0.05, respectively (2-tailed); SW, slaughter weight; WCW, warm carcass weight; HSLN, head, shoulder and neck; FLSL, forelimb and shoulder; HLR, hind limb and rump; BNR, breast, neck and ribs; LAW, loin and abdominal wall

The mean slaughter weight of male was $1450.00 \mathrm{~g}$, while it was $1451.33 \mathrm{~g}$ for female rabbit at 6 months. The warm dressing percentages were $47.74 \%$ and $48.55 \%$ for male and female rabbits, respectively. The mean values for slaughter weight, carcass weight and dressing percentage of male and female rabbits observed in the present study were similar to those described by some researchers (Yalçın et al. 2001), and lower than those reported by others (Skrivanova et al. 1999; Piles et al. 2000; Dal Bosco et al. 2002; Trocino et al. 2002). These differences might be due to the variation of slaughter age, breeding, weaning age and feeding conditions (Deltoro and Lopez 1986; Fernandez and Fraga 1996). Slaughter weight and carcass weights were slightly lower and dressing percentages were higher in males than that in females, but these differences were not significant in the present study. Similarly Trocino et al. (2002) also reported that females showed higher live weight $(p<0.05)$ but lower dressing percentage $(p<0.01)$ due to the higher incidence of the gut content. In contrast, according to the results of Pla and Cervera (1997) dressing yield was lower for males than for females. Slaughter weight was correlated to carcass weight and dressing percentage significantly (Table 2 ).

The mean of liver weight per $100 \mathrm{~g}$ live weight in the present study was similar with previous studies (Iyayi and Ngodigha 1991; Gupta and Atreja 1998; Yalçın et al. 2003). There was no significant difference between heart and kidney weight of male and female as shown in Yalçın et al. (2006). The values for carcass length were smaller and lumbar circumference values were larger than those of some researchers (Fernandez and Fraga 1996; Dal Bosco et al. 2002). Carcass length was correlated $(p<0.01)$ positively with carcass weight and dressing percentages and negatively with lumbar circumference. According to the results obtained by Fernandez and Fraga (1996), lumbar circumference and carcass lengths increased with slaughter weight. However, in the present study low correlation coefficients were obtained between slaughter weight and these carcass measurements. No differences in these measurements between males and females were found in the present study. The percentage values of the fore legs and hind legs were in agreement with those reported by some researchers (Pla et al. 1998; Piles et al., 2000; Yalçın et al. 2003). The results for the percentage values of loin and abdominal wall were similar to those obtained in other experiments with New Zealand White rabbits (Deltoro and Lopez 1986; Chiericato and Filotto 1989). The weights of the fore legs, hind legs, breast and ribs, loin and abdominal wall were correlated positively $(p<0.01)$ with slaughter weight, carcass weight and dressing percentage. However the values for the percentages of breast and ribs, fore legs and hind legs were higher than the results of Deltoro and Lopez (1986). There were no differences between female and male in the weight and percentages of these carcass traits. 


\section{Carcass and meat characteristics of rabbit}

Table 3 indicates the cooking loss of male and female rabbits. Cooking loss percentage was 28.22 and 27.69 respectively for male and female which were similar to those obtained by Pla et al. (1998) and higher than those found by some researchers (Pla and Cervera 1997; Trocino et al. 2002). No differences between sexes were observed in this study. Table 3 also indicates the drip loss of male and female rabbits. Drip Loss was found $2.74 \%$ and $2.78 \%$ in male and female, respectively which shows no significant difference.

Table 3. Mean values and SE values of cooking loss and drip loss

\begin{tabular}{lccc}
\hline & Male & Female & Sig. level \\
\hline Cooking Loss (\%) & $28.22(0.10)$ & $27.69(0.03)$ & NS \\
Drip Loss (\%) & $2.74(0.15)$ & $2.78(0.12)$ & NS \\
\hline
\end{tabular}

NS, not Significant

Table 4 indicates proximate components of male and female rabbit's meat. In case of proximate analysis crude protein percentage of male and female rabbits were 26.04 and 26.78 , respectively which is higher than Elamin et al. (2013). But no significant difference between male and female was found. Ash was found higher in male $(0.99 \%)$ than that of female $(0.90 \%)$ which was similar to Elamin et al. (2013).

Table 4. Mean values and SE values of Proximate Analysis: (on the basis of dry matter)

\begin{tabular}{lccc}
\hline & Male & Female & Sig. level \\
\hline Dry matter (\%) & $21.47(0.20)$ & $23.15(0.04)$ & NS \\
Moisture (\%) & $78.53(0.11)$ & $76.85(0.17)$ & NS \\
Crude protein (\%) & $26.04(0.12)$ & $26.78(0.23)$ & NS \\
Ash (\%) & $0.99(0.01)$ & $0.91(0.02)$ & NS \\
\hline
\end{tabular}

NS, not Significant

Table 5 indicates the sensory study of male and female rabbit meat. In case of sensory study female rabbits meat found more suitable than male in respect of tenderness and overall acceptance. But incase visual inspection of meat male rabbit's meat was more colorful and had better odor than that of female.
Table 5. Mean values and SE values of sensory study

\begin{tabular}{lccccc}
\hline & \multicolumn{2}{c}{ Raw meat } & \multicolumn{3}{c}{ Cooked Meat } \\
\hline & Color & Odor & Tenderness & Juiciness & $\begin{array}{c}\text { Overall } \\
\text { Acceptance }\end{array}$ \\
\hline Male & $3.6(0.01)$ & $4(0.00)$ & $3.8(0.12)$ & $3.6(0.01)$ & $4.2(0.02)$ \\
female & $3.2(0.01)$ & $3(0.00)$ & $4.2(0.03)$ & $3.4(0.02)$ & $4.8(0.01)$ \\
\hline
\end{tabular}

1, poor, 2, fair, 3, good, 4, very good, 5, excellent

\section{Conclusion}

The present study revealed that there is no significant difference between male and female rabbit meat except head, skin and limbs weight. Mature rabbit can be used as a source of protein for human because of its higher protein percentage.

\section{References}

Akıncı Z, Poyraz Ö, Akçapınar H, Evogliyan N (1998). The effects of genotype, sex and age on some slaughter traits and carcass characteristics of New Zealand White and California Rabbits. Journal of Lalahan Livestock Research Institute, 38: 84-102.

AOAC (Association of Official Analytical Chemists) (2005). Official Methods of Analysis, Association of Official Analytical Chemists. $13^{\text {th }}$ Ed., Washington, DC. P. 957.

Cavani C, Bianchi M, Lazzaroni C, Luzi F, Minelli G, Petracci M (2000). Influence of type of rearing, slaughter age and sex on fattening rabbit: II. Meat quality. In: Proceeding of the $7^{\text {th }}$ World Rabbit Congress, Spain, Volume A: 567-572.

Chiericato GM, Filotto U (1989). A note on the fattening performance and carcass characteristics of New Zealand White, Hyla and Provisal rabbits. Journal of Applied Rabbit Research, 12: 156-158.

Dal Bosco, Castellini AC, Mugnai C (2002). Rearing rabbits on a wire net floor or straw litter: behavior, growth and meat qualitative traits. Livestock Production Science, 75: 149-156.

Dalle ZA (2002). Perception ofrabbit meat quality and major factors influencing the rabbit carcass and meat quality. Livestock Production Science, 75: 11-32. 
Damron WS (2003). Introduction to Animal Science. Global, Biological, Social, and Industry Perspectives. $2^{\text {nd }}$ Edition, Prentice Hall, New Jersey. P. 670.

Dawson B, Trapp RG (2001). Basic and Clinical Biostatistics. 3rd Ed. Lange Medical Books/ McGraw-Hill Medical Publishing Division, New York.

Deltoro J, Lopez AM (1985). Allometric changes during growth in rabbits. Journal of Agricultural Science, 105: 339-346.

Deltoro J, Lopez AM (1986). Development of commercial characteristics of rabbit carcasses during growth. Livestock Production Science, 15:271-283.

Elamin K, Khalid M (2013). Sex Effects on Carcass and non carcass traits of Sudanese mature Belladi rabbits. Wayamba Journal of Animal Science, 5: 604-608.

FAOSTAT (2010). FAOSTAT Agriculture Data. Food and Agriculture Organization of the United Nations.

Fernandez C, Fraga MJ (1996). The effect of dietary fat inclusion on growth, carcass characteristics, and chemical composition of rabbits. Journal of Animal Science, 74: 2088-2094.

Gupta HK, Atreja PP (1998). Influence of ferric chloride treated Leucaena leucocephalaon metabolism of mimosine and 3-hydroxy $4(1 \mathrm{H})$-pyridone in growing rabbits. Animal Feed Science and Technology, 74: 45-55.

Iyayi EA, Ngodigha E (1991). Performance and organ weights of rabbits fed diets with graded levels of cassava peel and palm oil. Journal of Applied Rabbit Research, 14: 152-154.

Ouhayoun J, Delmas D (1988). Meat quality of rabbit: I. Differences between muscles in postmortem $\mathrm{pH}$. In: Proceeding of the $4^{\text {th }}$
World Rabbit Congress, Budapest, 2: 412 418.

Piles M, Blasco A, Pla M (2000). The effect of selection for growth rate on carcass composition and meat characteristics of rabbits. Meat Science, 54: 347-355.

Pla M, Cervera C (1997). Carcass and meat quality of rabbits given diets having a high level of vegetable or animal fat. Animal Science, 65: 299-303.

Pla M, Guerrero L, Guardia D, Oliver MA, Blasco A (1998). Carcass characteristics and meat quality of rabbit lines selected for different objectives: I. Between lines comparison. Livestock Production Science, 54: 115-123.

Skrivanova V, Marounek M, Klein P (1999). Effects of virginiamycin and salinomycin on performance, digestibility of nutrients and mortality of rabbits. Animal Feed Science and Technology, 77: 139-147.

Trocino A, Xiccato G, Queaque PI, Sartori A (2002). Effect of transport duration and sex on carcass and meat quality of growing rabbits. In: Proceeding of 2nd Rabbit Congress of the America, Cuba. P. 232-235.

Yalçın S, Onbaşılar EE, Onbaşılar İ (2006). Effect of sex on carcass and meat characteristics of New Zealand White rabbits aged 11 weeks Asian-Australasian Journal of Animal Sciences, 19: 1212-1216

Yalçın S, Tuncer İ, Yalçın S, Onbaşılar EE (2003). The use of different levels of common vetch seed (Vicia sativaL) in diets for fattening rabbits. Livestock Production Science, 84: 93-97.

Yalçın, S, Hacıoğlu E, Gürdoğan T, Oğuz N, Onbaşılar İ (2001). The usage of poplar sawdust in the rations of rabbit as a source of fiber. Journal of Poultry Research, 3: 47 52. 